\title{
The Suobo staff in custom and tale. Ginseng seekers'material culture in Jilin Han folk literature
}

Mareile Flitch

\section{(2) OpenEdition}

12 Journals

Electronic version

URL: https://journals.openedition.org/tc/444

DOI: $10.4000 /$ tc. 444

ISSN: 1952-420X

Publisher

Éditions de l'EHESS

Printed version

Date of publication: 1 May 1998

ISSN: 0248-6016

\section{Electronic reference}

Mareile Flitch, "The Suobo staff in custom and tale. Ginseng seekers'material culture in Jilin Han folk literature", Techniques \& Culture [Online], 29 | 1998, Online since 28 October 2005, connection on 29

September 2022. URL: http://journals.openedition.org/tc/444 ; DOI: https://doi.org/10.4000/tc.444

This text was automatically generated on 29 September 2022.

All rights reserved 


\section{The Suobo staff in custom and tale. Ginseng seekers'material culture in Jilin Han folk literature}

Mareile Flitch 